\title{
The Effect of Entrepreneurship Education on Business Intelligence of Management Students of Islamic Azad University of Elam
}

\author{
Roghaieh Fathi \\ Department of Educational Sciences, Islamic Azad University, Elam Branch, Elam, Iran \\ E-mail address: rahbord10@gmail.com
}

\begin{abstract}
This study was performed with the goal of determination of effect and relationship between business intelligence and entrepreneurship education and response to this question that entrepreneurship education can be effective on Business intelligence of student? Considered Population sample is that samples matched through matching by gender in two 28 people groups, in each group (14 boys and 14 girls) simple randomly method. The study is performed based on comparison-scientific method. The results of study show that entrepreneurship educations have positive and meaningful effect on business intelligence of students who participated in entrepreneurship educations classes. And also results show that the amount of observed beta in entrepreneurship dimensions for locus of control variables, Mental health, Pragmatic, dreaming, Challenging, entrepreneurship in order are $.235,279,335,231,293,317$ that each six numbers are in the 0.01 meaningful level. It means that every six variables meaningfully have the Predictive power of business intelligence of students in both female and male gender.
\end{abstract}

Keywords: entrepreneurship; entrepreneurship education; business intelligence

\section{INTRODUCTION}

Accelerating changes of current world in scientific and technical eras and subsequent challenges of economic- social system, decreasing of groundwater reserves and increasing of poverty and unemployment due to more attention of policymakers and scholars to entrepreneurship concept, as far as they consider the last model of development for development based on entrepreneurship (Ahmadpourdariani, 2007). Hesrich \& Piters (2002) known entrepreneurship as something beyond efforts worth and the time that consumed for it. Although entrepreneur, received personal and financial satisfaction (internal) as rewards resulting from his/her efforts of it (entrepreneurship). Simultaneously, by unfolding of role and effect of entrepreneurship on employment trends and economic growth in developed countries, effort for education and generalizing of knowledge and entrepreneurial spirit 
among the managers, merchants, students and potential entrepreneurs was strongly(Ahmadpourdariani, 2007). Entrepreneurship education in many developed countries an even in the developing countries posed as one necessity and this thought that entrepreneurs have inherent feature is rejected (Akbari, 2005).

Gib, Clark and Mack Freson known entrepreneurship as systematic, Conscious and goal-oriented process that it uses for transferring of needed knowledge and information for entrepreneurship and it will be include improvement and development of attitudes and skills and abilities of non-entrepreneurs (Ahmadpourdariani, 2007). One of those things that expected create in entrepreneur person by entrepreneurship education is business intelligence (Jazayeri, 2007).

Todayes information and knowledge in third millennium convert to basic wealth of organizations and business and manufacturing units for obtaining competitive advantage follow the use as much of the wealth in their important decisions in todays ee dynamic environment. By implying information technology and communication in all of the principles of business and also organizational systems and software, form the business bed and convert to new resource for organizational data. Something completely clear is that for vital needs of today ${ }^{\text {ee }}$ organization and third millennium business, by using or without using of decision support systems, many researches and projects is performing for development of related tools to decision support such as Line analytical processing, data storage, searching the data, Expert Systems and smart elements and etc.

This technology and features are collected in new frame with name of business intelligence or decision support environment (Alter, 2004). As regard that entrepreneur is a person who organizes, manages and assumes the risks of a business development (Alter, 2004). Therefore business intelligence and entrepreneurship in one commercial system or unit are necessary and interdependent of each other. Due to posed contents this study was performed with the goal of determination of effect and relationship between business intelligence and entrepreneurship education and response to this question that "entrepreneurship education can be effective on Business intelligence of student"?

\section{THEORETICAL PRINCIPLES AND THE BACKGROUND OF THE RESEARCH}

\section{1. Entrepreneurship}

The term of entrepreneurship originated from French term" Entrepreneur" means "Pledge" (Akbari, 2005). Entrepreneurship is not a new conception, but the root of it comes back to eighteenth century. Means the time that Richard Kantilon divided economic factors in three categories: Esquires, economic factors of wage earners and the group of economic factors who work with risk acceptance in the stock market (Ravasizare, 2012).

Entrepreneurship is the process that begin with opportunity-oriented view of entrepreneur and the it $\mathrm{el}$ result is service delivering and new production and create jobs and prosperity in the society. Jeffry Tenonez 4, known entrepreneurship as creating worthy phenomena from nothing. In other words, entrepreneurship is main factor of changing and stimulating of the development that due to continuous creativity and innovation (Ahmadpourdariani, 2007).

Based on Max Weber idea 5, entrepreneurship is social process that entrepreneur with passion and perseverance in work, finds himself and releases from common traditions and habits (Ravasizare, 2012). 


\section{2. Types of entrepreneurs}

This question that: (who is entrepreneur?) before any subject of entrepreneurship has been investigated. The evidences show that entrepreneurs generally have certain features. Such as high level of motivation to successfulness of inherent control center and tolerance of ambiguity. It isn"et seem that those features are just features of an entrepreneur but it is possible that help the entrepreneur recognizing of different categories. For example (Esmit and Miller) separated skillful entrepreneurs from (opportunists) and consider this point that opportunists are adaptable and growth-oriented. In this part determined four types of entrepreneurs that included;

- Entrepreneurs who emphasize on bold movement and motivate for successfulness.

- Entrepreneurs who make business and work about retailing the networking

- Entrepreneurs who emphasize on innovation and creativity.

- Those who motivate for power and have tendency for leadership. Of course one person may be exist in more than one category (Jazayeri, 2007).

\section{3. Conception and importance of entrepreneurship}

In a simple definition, entrepreneurship education is systematic, informative and goaloriented process that during of it the non-entrepreneur but having potential ability are trained in the creative way. In fact, entrepreneurship education is an activity that use it for transferring of needed knowledge and information for entrepreneurship that it will be include the increasing, improvement and development of attitudes, skills and abilities of nonentrepreneurs people. In other words, entrepreneurship educations follow improvement and motivation in people tendencies like seeking opportunities, creativity, taking risk and etc. and finally the aim of entrepreneurship education is training of creative and innovative people (Ahmadpourdariani, 2007).

Currently education, is one of the important aspects in entrepreneurship development that take specific attention. But the status always is not like this and in the past it was common idea based on that entrepreneurs have inherent features such as creativity, oppressive spirit, movement, tendency to taking the risk, analytical ability and skillfulness in humanistic relationships, and was born with those features.

The main suppose on this course is that entrepreneurs didn ${ }^{e e}$ train by education, therefore until the role of education didn ${ }^{e c} t$ exist in creating and development of entrepreneurship and only emphasized on artistic aspect of entrepreneurship. But something that modifies this thought is the results of different studies that show that entrepreneurs ,features often are acquisitive and it is not inheritance and in this way currently entrepreneurship education is became one of the most important and most development activities of universities, because necessity for entrepreneurship development, is education of it (Karami, 2011).

\section{4. Entrepreneurship education goals}

Generally, the considered goals in entrepreneurship education are as follow:

a) Acquiring knowledge related to entrepreneurship: much knowledge can be acquired in fields such as entrepreneur definition, entrepreneurship, entrepreneurship history, the features of entrepreneurs people, theoretical course of entrepreneurship discussions, entrepreneurship advantages, and biography of great entrepreneurs.

b) Solving of employment problems and improve of productivity: in one hand agriculture less can be more employment and in another hand learning and entrance to beneficial 
works also can't be possible for everyone, it seems that entrepreneurship education is the appropriate way for solving of employment problems and improve of productivity.

c) Recognition and stimulation of talents and entrepreneurial skills: making and promoting the values, attitudes and entrepreneurial behaviors need recognition and stimulation of talents and ite $\mathrm{s}$ skills. This aim generally in political frame and encouragement programs, promotional and instructional is tracked.

d) taking risk induction by using analytical technics: for entrepreneurship should have romance and subtle braveness that itself depended on two factors, one of them is Confidence (for learning something that we don ${ }^{\text {eet }}$ know) and other is braveness ( for facing with failure or taking-risk)

Revised in order to adapt to changing attitudes: entrepreneurship is one of the factors that due to growth and economic development of countries in this age. This key role of entrepreneurship more than anything focused on organizational structurese flexibility and applying continuous and dynamic change in systems, processes and finally goods and services (Karami, 2011).

\section{5. Entrepreneur Types}

This question that: (who is entrepreneur?) More than any kind of subject has been investigated, while it has certain characteristics. Such as: high level of motivation to successfulness of internal controlling center and bearing the ambiguity. It doesn ${ }^{\text {ee }}$ seem that those characteristics are just characteristics of one entrepreneur, indeed it is possible help to recognition of different kinds of entrepreneurse ${ }^{\text {ce }}$ categories. For example (Smith \& Miller) skillful entrepreneurs separated from (Opportunists) and they pay attention to this point that opportunists are adaptable and they are growth- oriented. Here, determine four kinds of entrepreneurs that include:

- Entrepreneurs who emphasize on bold movements and motivate for success.

- Entrepreneurs who emphasize on innovation and technology.

- Those who motivate for power and they have tendency toward leadership. Indeed, a person may be exists in more than one category (Mohammadian, et al., 2010).

\section{6. Empirical Foundations of Entrepreneurship Education:}

Today, the primary disagreement of researchers has been vanished about creating or making entrepreneurs and the public know that entrepreneurship is taught able. In the past, one of the main disagreement among researchers of entrepreneurship is recognition of entrepreneurial behavior origin. Jacobowitz (1994) by interview with more than 500 entrepreneurs during three years concluded that personality characteristics of entrepreneurs are more similar with each other. There for he concluded those entrepreneurs are born with this characteristic and they don ${ }^{\mathrm{ee}} \mathrm{t}$ treat. Later entered to this criticism view and researchers based on sharps ${ }^{\text {ee }}$ model and investigation of environment effect show that entrepreneurse behavior is planned and voluntary.

Therefore against primary views that assumed entrepreneurs instead of making, they are born and its characteristics is specific and rare that it isn ${ }^{e e} t$ find in everywhere. Today it is determined that entrepreneurs instead of boring, they are made. Therefore, the opinions about entrepreneurship education is posed: such as Gasse (1985) advised that entrepreneurship in high schools is educated when the determination of employment way is opened. Kent knew, the way of entrepreneurship education for elementary and high school students was weak and pointed to three levels of entrepreneurship education levels include motivate the potential 
entrepreneurs (in elementary level school), inspire the potential entrepreneurs (high school level) and necessary education skills for entrepreneurship (in the university level).

Therefore until 1990 shaped four main classes of entrepreneurship education included: awareness and orientation toward entrepreneurship, development of firms establishment, growth and survival of entrepreneurship and small firms and development of new methods of entrepreneurship education (Ahmadpourdariani, 2007).

Thus, we can concluded that making entrepreneurial behaviorse indexes in the way of education has the most important effect on entrepreneurship detection. Finally, in spite of importance that it has on entrepreneurship education in detection of entrepreneurial behaviors indexes and as a result entrepreneurial behaviors in external and internal research pay less attention to it. For example: research of Moshaf and colleagues (2006), Mahrabi Razveh (2006), barani and colleagues (2011), Saidi Mehrabadi and Mohtadi (2009), Jones and English (2004), Oosterbeek, et al (2010).

Effectiveness of entrepreneurship education on changing of entrepreneurial view, entrepreneurship behavior as whole or on recognition of entrepreneurship behavior opportunities has been investigated and they avoided by investigation of effectiveness of entrepreneurship education means making decision, recognition of opportunities, determination of structures, determination of sources and determination of methods (Sarlak, et al, 2011).

\section{7. Business Concept and Innovator work:}

Generally entrepreneurship means opportunism that one opportunity can be make as the one appropriate set of conditions and a need or explain of business concept.

Business concept refers to capitalize on new opportunities as the unique and innovative factors. This characteristic can reflect in production or providing service in business or in some adventure operation such as delivering methods or pricing approach.

- frameworks of innovation types:

- Being a new product or service in the world

- Being a new product or service in the market country

- Being a new product or service of institute if there is a competitor

- adding to production line or service of institute

- production improvement and modified service include applying of new characteristics for new section or new changes.

- establishment of service again or new production

- improvement of processes that due to value for customer, increasing of productivity and decreasing of expenses

- performing system or new method

- structure or new organizational shape

- new method for producing

- selling approach or new marketing

- channel and new method of distribution

- the program for supporting the new customer

- the new strategic approach

- the new method of supplying financial resources

- the new method of pricing

- the new technique of purchase (Mohammadian, et al., 2010). 


\section{8. Business Intelligence}

Business intelligence is one great and like- umbrella that for the first time by Hoard Dersener from the group of charter in 1989 for description the set of concepts and methods for improvement of business decision making by using computer support system is posed.

The first scientific definition of Business intelligence performed by Goshal and Kim (1986) in this way that "a management philosophy and instrumental philosophy for helping the organization for management and business information with the effective decision making in the business environment". Akerson (2010) made this view that Business intelligence should have ability for making tools such as reports, analytical interview, OLAP, Dashboards, data mining techniques and planning toolsand modeling.

Lonkuvist and pier Timakei (2006) expressed that business intelligence modification can apply for two follow concept:

1) Information and related knowledge of organization that business environment, organization, market conditions, costumer, competitors, Stakeholders and concerns of such things are described.

2) Systematic processes that apply by organization for acquisition, analyzing and delivering of information for decision making about business.

The literature review in Business intelligence domain of (division) showed attempts for defining of this concept. This division is summarized in two view of management and technical with two different pattern. Management approach sees business intelligence as one process that the data are collected from outside and inside of organization and become integrated that can make the related information with making decision process. The role of Business intelligence in this view is created the informational environment and space that the data of acquisition operations from transactional processing systems and outside resources can be analyzed to supply the knowledge for business and making decision of unstructured business. Technical approach, considers Business intelligence as set of tools that supplies the above mentioned processes.

The focus of this approach is not on processes but is on technologies, algorithms and tools that provide ability of saving, recovering, collecting and analyzing of data and information (Elbashir, et al, 2008). Any way in general view, two important issues are discussable. First, the core of Business intelligence are collecting, analyzing and delivering of information and second the aim of Business intelligence is supplying the making decision process in organization (Elbashir, et al, 2008). Buss (2009) also know management approach to Business intelligence as process for giving true information to true people in appropriate time for making decision that the result of them can improve the function of organization. View and technical approach to Business intelligence usually focused on functions and technologies for collecting, saving, analyzing and accessibility to data for Business intelligence concept completion. An important issue that it has been saw in Business intelligence concept completion is the changing of suppliers approach for servicing and Business intelligence in past toward Business intelligence in the future. That it can make the provision for organizations. Those suppliers make Business intelligence abilities for different needs of business and analytical capabilities of growth and due to Value Added.

Growth and amount of revenue on Business intelligence systems (Business intelligence capabilities) Reflects the growing strategic importance of them and highlights the needing by attention and functional researches (Hesrich, 2002). In some researches Business intelligence with integrating and changing the raw data to key indexes of related function. The key indexes of function show necessary basics for business decision that they are related to 
business process of organization. In fact the recording of details and the operational process of information in analyzing space of data, interpretation of information and making appropriate decision (Bucher, et al, 2009). Recently Jalonen and Lonkovist (2009) expressed that Business intelligence of analyzing and reports about Climate trends of business and produce the inside problems of organization and those analyzing can be prepared automatically and systematic or based on request or special conditions and they are related to Climate trends and acquired knowledge applies by decisions at various levels of the organization. Based on above definitions we can expressed two main assumptions about business intelligence. The first is looking to Business intelligence, the looking to supplier activity from organization management with analytical information of decision oriented in different managerial activities (Ravasizare, 2012).

\section{RESEARCH METHOD}

The current research, is based on comparison - scientific method. In this research, the business intelligence of students of one class in management field that they passed entrepreneurship lesson compared with business intelligence of students who they didn ${ }^{\text {ee }}$ pass this lesson. For low numbers of samples, Targeted sampling is used. For evaluating of entrepreneurship characteristics Questionnaire to identify entrepreneurs is used. For investigating of Validated tool to identify Aboriginal Iranian Entrepreneurs, the kornbach alpha method is used.

The overall validity of this questionnaire equals to 0/92. For evaluating of business intelligence of students also 23 items questionnaire of Provitch (2012) has been used that the validity is acquired by $0 / 84$ alpha method. For analyzing of data also independent $-t$ test is used.

\section{1. Findings}

\section{Gender of respondents}

Demographic data showed that 86 people of sample in this research 60 percent of them (52) in statistical sample in this research are women and 40 percent of studied students (34) are men. That among those numbers 40 people are under entrepreneurship education that 14 cases of them are men students and 26 of them are women. Samples by gender matching in two groups of 28 people are matched with randomly method that in each group exist (14 boys and 14 girls).

\section{First hypothesis: Entrepreneurship education in business intelligence for students has the positive effect}

The results of Table 1 show that there isn't a meaningful difference between score of business intelligence of educated people and uneducated people of Entrepreneurship Group. That the observed amount of $\mathrm{t} 1 / 87$ with freedom degree 54 times bigger than crisis amount.

Then with 950/0 sureness, we can say that our hypothesis is based on Entrepreneurship education has positive effect on business.

Intelligence of students is proved $(p<0 / 05)$. 
Table 1. Difference between of business intelligence of educated people and uneducated people of Entrepreneurship Group.

\begin{tabular}{|c|c|c|c|c|c|c|c|c|}
\hline $\begin{array}{l}\text { Statistical } \\
\text { Indicators }\end{array}$ & Numbers & Mean & $\begin{array}{l}\text { Standard } \\
\text { Deviation }\end{array}$ & $\begin{array}{c}\text { Standard } \\
\text { error }\end{array}$ & $\begin{array}{c}\text { Mean } \\
\text { difference }\end{array}$ & $\begin{array}{c}\text { The } \\
\text { amount } \\
\text { of } \mathrm{t}\end{array}$ & $\begin{array}{l}\text { Degrees } \\
\text { of } \\
\text { freedom }\end{array}$ & $\begin{array}{c}\text { Meaningful } \\
\text { level }\end{array}$ \\
\hline $\begin{array}{c}\text { Business } \\
\text { intelligence- } \\
\text { Education } \\
\text { Entrepreneurship } \\
\text { group }\end{array}$ & 28 & $2846 / 8409$ & $4 / 95141$ & $0 / 43097$ & $2 / 22$ & $1 / 87$ & 54 & $0 / 21$ \\
\hline $\begin{array}{c}\text { Business } \\
\text { intelligence of } \\
\text { uneducated } \\
\text { Entrepreneurship } \\
\text { group }\end{array}$ & 28 & $48 / 0667$ & $5 / 71617$ & 0/49179 & & & & \\
\hline
\end{tabular}

\section{Second hypothesis: there is a relation between octal dimensions of Entrepreneurship and business intelligence in the female and male students.}

For investigation of relation between entrepreneurship dimensions and business intelligence used regression. Its results presented in Table 2.

Table 2. $r_{2}$ the regression equation of entrepreneurship and business intelligence.

\begin{tabular}{|c|c|c|c|c|}
\hline Model & $\begin{array}{c}\text { Multiple correlation } \\
\text { coefficient }\end{array}$ & $\begin{array}{c}\text { Determination } \\
\text { coefficient }\end{array}$ & $\begin{array}{c}\text { Standardized } \\
\text { determination } \\
\text { coefficient }\end{array}$ & $\begin{array}{c}\text { Standard error } \\
\text { correlation } \\
\text { coefficient }\end{array}$ \\
\hline 1 & $0 / 425$ & $0 / 180$ & $0 / 163$ & $4 / 31330$ \\
\hline
\end{tabular}

Table 2 shows that the amount of integrated correlation of entrepreneurship variables with the business intelligence of students equals $0 / 43$ and the amount of Determination Coefficient equals $0 / 018$ and also the adjusted amount of $r 2$ equals $0 / 0163$.

Table 3. Analyzing and variance of entrepreneurship education and business intelligence.

\begin{tabular}{|c|c|c|c|c|c|}
\hline Model & $\begin{array}{c}\text { The sum of } \\
\text { Squares }\end{array}$ & $\begin{array}{c}\text { Freedom } \\
\text { degrees }\end{array}$ & The mean of squares & F & Meaningfulness \\
\hline $\begin{array}{c}\text { Regression } 1 \\
\text { The whole }\end{array}$ & 320.985 & 8 & 191.664 & \\
reminder & 4353.476 & 48 & 18.605 & 10.302 & 000. \\
\hline
\end{tabular}


The results of Table 3 shows the meaningfulness of regression. that the amount of $\mathrm{F}$ equals to $10 / 32$ of 8 and 48 freedom degrees that it is bigger the number of table and the amount of meaningfulness level is smaller than $0 / 01$. Therefore zero assumption is based on lack of relation. Due to meaningfulness of regression, the entrepreneurship variables with business intelligence related to prediction equation presented in Table 4.

Table 4. The regression coefficients of the entrepreneurship and business intelligence.

\begin{tabular}{|c|c|c|c|c|c|}
\hline model & B coefficients & Standard error & $\begin{array}{c}\text { Standard } \\
\text { coefficients }\end{array}$ & $\mathrm{T}$ & meaningfulness \\
\hline Fix numbers & 17.927 & 4.991 & & 3.592 & .000 \\
\hline Balanced risking & .045 & .059 & .055 & .770 & .442 \\
\hline Control center & .0190 & .047 & .279 & 4.040 & .000 \\
\hline $\begin{array}{c}\text { Need to success } \\
\text { Healthy of } \\
\text { thought }\end{array}$ & .030 & .053 & .034 & .554 & .580 \\
\hline $\begin{array}{c}\text { Functionalism } \\
\text { Ambiguity }\end{array}$ & .231 & .062 & .235 & 3.722 & .000 \\
\hline $\begin{array}{c}\text { tolerance } \\
\text { Dreaming }\end{array}$ & .037 & .056 & .317 & 4.605 & .000 \\
\hline Challenging & .213 & .055 & .048 & .0671 & .503 \\
\hline entrepreneurship & .255 & .044 & .0293 & 4.262 & .000 \\
\hline
\end{tabular}

Also the results of Table 4 shows that the amount of beta for control center variables, healthy of thought, functionalism, dreaming, challenging, entrepreneurship in order are 279.235.317. 0239.231. 335. That each six numbers are in the $0 / 01$ of meaningfulness level. It means that each six variables have the meaningful prediction power for business intelligence of student in both female and male gender.

\section{DISCUSSION AND CONCLUSION}

This research with the aim of effect and relation between business intelligence and entrepreneurship education and response to this question that is entrepreneurship education can be effective on exciting intelligence of student? Is performed, the results of research showed that entrepreneurship educations have positive and meaningful effect on business intelligence of students who participated in the entrepreneurship education classes. Also the results showed that entrepreneurship dimensions for control center, healthy of thought, functionalism, dreaming, challenging, entrepreneurship in order are $.279, .235, .317,0239$, $.231, .335$, that each six numbers are in the $0 / 01$ of meaningful level. It means that each six variables with meaningfulness prediction power of business intelligence of students in both female and male gender. 
Although up to now about the relation of two variables don et perform a survey inside or outside indirectly (entrepreneurship education and exciting intelligence). But it can be interpreted that the data from this research with the results of Mehrabi Rozeh (2006) show that employment consultant has effect on increasing of entrepreneurial behaviors ${ }^{\text {ee }}$ jobseekers. The research of Abedi equated by Mehrabi (2006), show that the effectiveness of entrepreneurship education on detection of entrepreneurial behaviors and by the research of Jones and English (2004) that based on the effectiveness of entrepreneurship education on increasing of individualse ${ }^{e}$ abilities for recognition of business opportunities and detection of entrepreneurial behaviors (Ravasizare, 2012).

Indirectly have the consistent. Based on it can be say that entrepreneurship is not the inherent characteristic of human, also it can be say it shapes and encourages by using entrepreneurship education in the individuals, also due to knowledge and information in third millennium, it is change to main wealth of organization and commercial companies and production units for acquiring competition advantage for using more wealth in their risking decisions in dynamic environment of this days and by applying information technology and communication shape all business units and change it to new resource for organizational data that necessity of attention to results of research it can be predict that entrepreneurship education as one effective element has effect on encouragement of this dimension of intelligence (business) and shape this idea that it is necessary accompanying with business intelligence system performance in organization and commercial companies and producing units put emphasize on entrepreneurship education of individuals.

\section{Comments:}

1) System or organization aimed go toward intelligent, necessarily the entrepreneurship education courses held accompanying with intelligent.

2) Present fix and obligatory entrepreneurship course and also courses related to making and transferring the knowledge, competence and attitude of entrepreneurship based on expert and field of students.

3) Encouragement and optimization of entrepreneurship culture among students:

4) Planning and designing of entrepreneurship content and business intelligence for avoiding from waste of time and expense

5) Use teachers in teaching of entrepreneurship that they familiar with competition and business intelligence.

\section{References}

[1] Ahmadpourdariani M., Moghimi M. (2006). Foundations of entrepreneurship. Tehran: Farandish Publication.

[2] Ahmadpourdariani M. (2007). Entrepreneurship. Tehran: Sherkate Pardis Publication.

[3] Akbari K. (2005). The role of education system in developing entrepreneurship. First Conference on Employment and Higher Education System. Tehran: Jihade Daneshghahi Publications. The Unit of Tarbiat Modarres University.

[4] Alter S., Decision Support Systems 38(3) (2004) 319-327.

[5] Bielefeld W. (2008). Social Entrepreneurship and social Entrprise, 21st Century Management: A reference hand book, SAGE. Publications. 
[6] Bucher T., Gericke A., Sigg S., Business Process Management Journal 15(3) (2009) 408-429.

[7] Elbashir M. Z, Collier P. A., Davern M. J., International Journal of Accounting Information Systems 9(3) (2008) 135-153.

[8] Hesrich R., Piters M. (2002). The individual entreprenure inentrepreneurship. New York: MC Graw-Hill.

[9] Ranjan J., VINE 38(4) (2008) 461-475.

[10] Jazayeri A. (2007). Review and assess the effectiveness of training courses held at the National Iranian Steel Company. Third International Conference on Management.

[11] Karami M., Setaysh Barhaghi M., Journal of Management of Health Information 8(1) (2011) 102-111.

[12] Mohammadian M., Mohammedan Moslem (2010). Effective factors on entrepreneurial education and ways of obstacles. International Conference on Management of Innovation and Entrepreneurship. Shiraz.

[13] Ravasizare A., Journal of Management Studies 1(2) (2012) 105-121.

[14] S. Petter, W. H. DeLone, E. R. McLean, European Journal of Information Systems $17(3)$ (2008) 236-263.

[15] Sarlak M., Forati H. (2011). Advanced Information system, published in Payam Noor University, First edition; p. 312.

[16] Seid Hamed Hosseini, International Letters of Social and Humanistic Sciences 7 (2014) $67-75$.

[17] Nadeem Iqbal, Naveed Ahmad, Zeeshan Riaz, International Letters of Social and Humanistic Sciences 9 (2014) 14-25.

[18] Sakineh Ghayazi, Faranak Omidian, Mohammed Hosseinpoor, International Letters of Social and Humanistic Sciences 10(1) (2014) 51-61.

[19] Morteza Ziaee, International Letters of Social and Humanistic Sciences 10(2) (2014) 172-180.

[20] Gholamreza Jandaghi, Hamid Reza Irani, Ehssan Jandaghi, Zeinab Sadat Mousavi, Maryam Davoodavabi, International Letters of Social and Humanistic Sciences 15(1) (2014) 7-13.

[21] Gholamreza Jandaghi, Hamid Reza Irani, Ehssan Jandaghi, Zeinab Sadat Mousavi, Maryam Davoodavabi, International Letters of Social and Humanistic Sciences 15(1) (2014) 78-83.

[22] Heman Mahmoudfakhe, Morad Abdivarmazan, Toba Amini, International Letters of Social and Humanistic Sciences 15(2) (2014) 84-91. 